\title{
Taste of power brings conflict to West Germany's Greens
}

\section{Munich}

WEST Germany's effervescent Green Party of the early 1980 s has grown into a troubled adolescent. Accepting responsibility, the Greens are discovering, is not nearly as easy as challenging those in authority. Some of the party's naive idealism has been lost, replaced by bitterness.

This has been a rollercoaster year in German - and Green - politics. In January, more than three million voters gave the Greens 8.3 per cent in the Bundestag, their highest total ever. In the 17 May election in Rhineland-Palatinate. the Greens swept into an eighth Landtag (state parliament), an all-time high.

The election in Hesse on 5 April, when the Greens polled a record 9.4 per cent, should have been another reason to celebrate; they were even thinking of demanding a second cabinet portfolio in West Germany's only Social Democratic (SPD)/ Green coalition. But the SPD collapsed and the conservative Christian Democrats (CDU), led by Federal Environment Minister Walter Wallmann, formed Hesse's new government in a traditionally SPD bastion.

This was a nasty slap in the face for the Greens, who had been campaigning for the closing of two nuclear-fuel processing companies in the city of Hanau. The government of Hesse had even challenged in the courts the federal government's jurisdiction over the plutonium industry (which suit Wallmann has now withdrawn).

The election result in Hesse has had wider consequences. In Hamburg on 17 May, it seems that thousands of voters deserted the Greens for the SPD to head off a further victory by the CDU. At the same time, sniping between two rival Green factions that had begun after the Hesse election escalated into a war on 3 May, when three so-called "Fundis" were elected at a national party gathering to head the unpaid 11-member Vorstand (executive comittee) of the Green party. This election left the "Realist" faction of the party, known as "Realos", in distress.

The internecine debate has produced rhetoric as shrill as that heard from the Greens after Chernobyl, but they are now criticizing each other. "Realo" Otto Schily, a member of the Bundestag, has accused "Fundi" Jutta Ditfurth, the new Executive Committee speaker, of having an "insanely distorted image of reality" because she allegedly likened German census-takers to fascists.

Ditfurth says she simply meant that there is ne such thing as harmless data. Censuses taken under the Nazis revealed the identity of Jews, and the 1987 census forms also ask a question about religious affiliation. Ditfurth accused Schily and his allies of wanting to split the party.

The internal battle centres on differences of opinion about accepting power. The Fundis reflect the roots of the Green Party, which began in the late 1970 s as a grass-roots environmental movement, and advocate refusal to participate in an unjust and "inhuman" society. They demand a "restructuring" of society that will eliminate pollution, nuclear weapons and large corporations.

The Realos accept these ideals, but advocate very different means of achieving them. Their immediate goal is

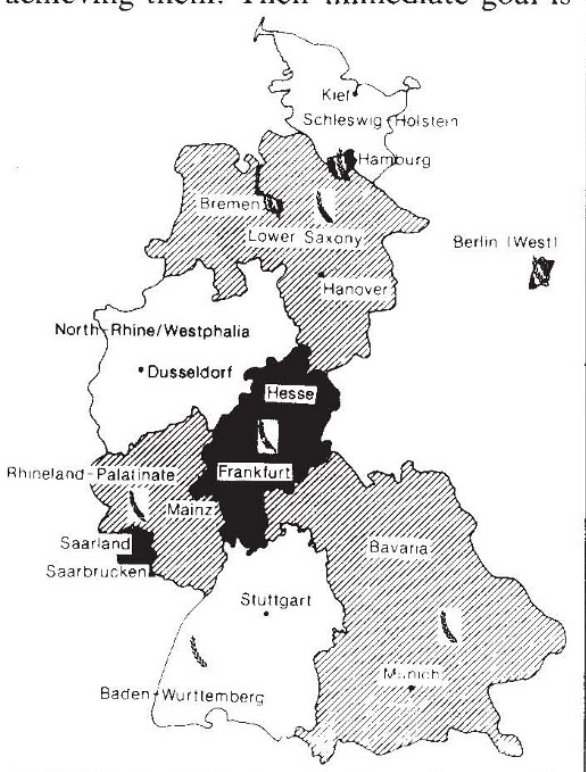

Eight Länder (wheat symbol) now have parliamentary representatives from the Greens.

to prevent right-wing governments from taking power and score visible political gains wherever possible. Barbara Rust, another Bundestag Green, says for example that shutting down some West German nuclear power plants would be acceptable if it were impossible to shut them all. She has criticized the Greens' conduct of the Hamburg election for not offering plausible conditions for a coalition with the SPD, saying that "Our supporters expect us to use every option available to us".

The Fundis disagree. Ditfurth reiterated after the Hesse election her earlier view that success at the polls is "not terribly important". According to Christian Schmidt, also on the Executive Committee, the Greens do not want to grow up.

The Greens, once proud to call themselves "the anti-party party", have become much like the others. Green Bundestag members are still paid less than others; the difference is put into an Ecofund for environmental projects. But the
Greens no longer rotate their Bundestag seats as was originally intended.

Political experience has changed much; some Green politicians (a phrase that would itself have seemed self-contradictory four or five years ago) seem to enjoy their positions of power. Yet they lack policies that are not simply criticisms of the other parties. Their anti-nuclear philosophy suffered a telling blow when, after Chernobyl, virtually nothing in the West German nuclear industry changed. "We knew that 80 per cent of the population wanted to switch off nuclear power", says Rust. "We have to ask ourselves if we've done something wrong."

The feud has created an "unaffiliated" wing of the party, called by one newspaper the "Neutralos", including roughly a third of the 44 Green Bundestag members. Led by Rust, the new group wants to distance itself from the battle.

But it offers little input as to how to broaden Green horizons. At worst, it seems just an "alternative within an alternative," not knowing just what it stands for. The danger for the Greens is that, having thrived on controversy, they may now turn to conflict within their own ranks on which to feed.

In what direction must the Greens go to maintain what little parliamentary influence they have? (Cold-shouldered by the other parties, they have sponsored only one successful bill - to ban turtlemeat imports - in the past four years.) A survey by the polling company INFAS showed that over 90 per cent of Green supporters in Hesse and Hamburg would have supported a coalition with the SPD, to which the Fundis are opposed.

Another INFAS survey has shown a steady downward trend of support among voters between 18 and 25 which Rust attributes to the Greens' refusal to come to terms with modern technology and so to offer young voters the prospect of finding jobs. Rust would seek to "convert current technologies" into less ecologically harmful jobs to bridge these demands.

But Green Bundestag member Christa Nickels is convinced that the recent spate of character assassination "scares people off," as do the radical slogans of the Fundis. Rust also faults the Realos for not taking intraparty disputes seriously enough, perhaps because they are too concerned with winning majorities. Now the best the Greens can hope for, it seems, is that the feuding will be stilled so that they can use the summer to prepare for the September elections in Schleswig-Holstein and Bremen.

Fundi Schmidt criticizes the Greens in general when he says that "what's missing here is the courage to practise alternative politics". But compromising also requires courage. The future for the Greens may depend on outgrowing its belligerent adolescence.
Steven Dickman 